\title{
EFFECT OF ORGANIC AMENDMENT ON STEM CANKER AND BLACK SCURF DISEASE OF POTATO (Solanum tuberosum)
}

\section{EFEITO DA ALTERAÇ̃̃O ORGÂNICA SOBRE O CANCRO DA HASTE E DOENÇA DOS TUBERCULOS PRETOS DA BATATA (Solanum tuberosum)}

\author{
M. M. RAHMAN ${ }^{1}$; M. A. ALI' ${ }^{2}$, T. K. DEY ${ }^{3}$; M.M. ISLAM ${ }^{4}$; M. U. AHMAD ${ }^{2}$; \\ K. M. KHALEQUZZAMAN \\ 1. Tuber Crops Research Sub-centre, BARI, Bogra, Bangladesh; 2. Department of Plant Pathology, BAU, Mymensingh, Bangladesh; \\ 3Pulses Research Centre, BARI, Ishurdi, Pabna, Bangladesh; 4. Tuber Crops Research Centre, Bangladesh Agricultural Research \\ Institute, Gazipur-1701, Bangladesh. monirupm.my@gmail.com; 5. Spices Research Centre, BARI, Shibganj, Bogra, Bangladesh
}

\begin{abstract}
An experiment was conducted at Tuber Crops Research Centre, BARI, Bogra during 2008-2009 to evaluate the organic amendment for controlling the stem canker and black scurf of potato. The different kinds of organic amendments were: $\mathrm{T}_{1}=$ Poultry refuse $(\mathrm{PR})$ at $4 \mathrm{tha}^{-1}, \mathrm{~T}_{2}=\mathrm{PR}$ at $5 \mathrm{t} \mathrm{ha}^{-1}, \mathrm{~T}_{3}=\mathrm{PR}$ at $6 \mathrm{t} \mathrm{ha}^{-1}, \mathrm{~T}_{4}=$ Mustard oil cake (MOC) at $300 \mathrm{~kg} \mathrm{ha}^{-1}, \mathrm{~T}_{5}=\mathrm{MOC}$ at $500 \mathrm{~kg} \mathrm{ha}^{-1}, \mathrm{~T}_{6}=\mathrm{Neem}$ oil cake $(\mathrm{NOC})$ at $300 \mathrm{~kg} \mathrm{ha}^{-1}, \mathrm{~T}_{7}=\mathrm{NOC}$ at $500 \mathrm{~kg} \mathrm{ha}{ }^{-1}, \mathrm{~T}_{8}=\mathrm{Sawdust}$ burning and $\mathrm{T}_{9}=$ Control. The experiment was laid out in a randomized complete block design (RCBD) with four replications. The organic amendment significantly influenced the disease incidence, yield attributes and yield of potato. The lowest disease incidence $\left(17.5 \%\right.$ ) and per cent disease index (9.99) were found in $\mathrm{T}_{3}$ (poultry waste at $6 \mathrm{t}^{\mathrm{a}^{-1}}$ ). The minimum russet, deformed and Sclerotia infected tubers were also recorded in poultry waste at $6 \mathrm{t} \mathrm{ha}^{-1}$. The highest healthy tubers and tuber yield were found in the same treatment. Therefore, poultry manure $6 \mathrm{t}^{-1}$ along with recommended dose of chemical fertilizer can be recommended to produce healthy tubers and maximum tuber yield of potato.
\end{abstract}

KEYWORDS: Organic soil amendment. Stem canker. Black scurf. Solanum teberosum.

\section{INTRODUCTION}

Potato is a very important vegetable crop in Bangladesh (HASHEM, 1990). It is used as food and cash crop in cool countries. It can meet the vegetable demand and provide necessary nutrients for the people from low income group (ISLAM et al., 2009). The average fields of potato in Bangladesh is $18.25 \mathrm{t} \mathrm{ha}^{-1}$, which is much lower than the other potato growing countries especially North America and Netherlands where potato is $41.3 \mathrm{t} \mathrm{ha}^{-1}$ (SWAMINATHAN, 2000). The major constraint of potato production in Bangladesh is prevalence of epidemic disease, the lack of quality supply of potato seed to the farmers (RAHMAN et al., 2014).

In Bangladesh, a total of 39 diseases both biotic (fungi, bacteria, virus, nematode, actinomycetes, mycoplasma) and abiotic (nutritional, physiological, environmental) of potato tuber have been recorded (ALI; KHAN, 1990). One of the major diseases is stem canker and black scurf caused by Rhizoctonia solani (Khun). It is the most common and widespread disease throughout the country (ALI; DEY, 1994). Rhizoctonia solani is a soil-borne and tuber-borne fungus and causes 'black scurf' on potato tubers and canker on stems. Severe stem canker can kill shoots and delay crop emerge (RAHMAN et al., 2014). The canker is commonly known as black scurf. The pathogen is also involved in the early dying syndrome of potato (KOTCON et al., 1985). In winter, the pathogen usually lives as mycelium or sclerotia in the soil and in or on infected perennial plants or propagative material such as potato tubers. Sometimes, the fungus may be carried in the seed. The fungus is present in most soils and once established in a field, remains there indefinitely (AGRIOS, 2005).

Organic amendment with poultry refuse (PR), poultry liter (PL), sawdust (SD) and mustard oil cake (MOC) was evaluated where poultry refuse was found to be effective in controlling stem canker and black scurf of potato and showed the maximum yield (DEY et al., 2005). Many researchers attempted to control black scurf and stem canker of potato Integration of different approaches has also been attempted in different countries (RAHMAN, 2011). However, there is no sufficient report for controlling the black scurf and stem canker of potato in Bangladesh (RAHMAN et al., 1996). Under this circumstance, developing a package for controlling the diseases is of prime need. Therefore, the present study was initiated to evaluate the organic amendment in soil for controlling stem canker and black scurf of potato. 


\section{MATERIAL AND METHODS}

\section{Experimental site and crop characteristics}

The field study was carried out at Tuber Crops Research Centre, Bangladesh Agricultural Research Institute (BARI), Bogra during the period from November 2008 to April 2009. The experimental site is located in Tista Meander Floodplain Soil (AEZ-3) at about N-24 $78^{\prime}$ and E$89^{\circ} 35^{\prime}$ having a mean elevation of $22 \mathrm{~m}$ above mean sea level and about $196 \mathrm{~km}$ north-west of Dhaka city. The experimental site was a high land having sandy loam soil. The soil was acidic ( $\mathrm{pH}$ 5.6) in nature. In Bangladesh, there are three cropping seasons namely Rabi, Kharif-I and Kharif-II. Rabi season started from the middle of October to the middle of March, Kharif-I season stretches from the middle of March to the end of June and Kharif-II season stretches from early July to the middle of October. The potato was grown in Rabi season. The test crop was potato (Solanum tuberosum L.) cv. BARI-7 (Diamant) and collected from the Breeder Seed Production Centre, Debigonj. The tuber of BARI-7 is white, oval, medium to large, smooth skin, light yellow flesh, eye shallow. Yield is 25-35 $\mathrm{t} \mathrm{ha}^{-1}$ and life is $90-95$ days. It is the most popular variety in Bangladesh.

\section{Experimental Design, Manure and fertilizer application and other intercultural operations}

The experiment was laid out in a randomized complete block design (RCBD) with four replications. The different kinds of organic manures were: $\mathrm{T}_{1}=$ Poultry refuse $(\mathrm{PR})$ at $4 \mathrm{t} \mathrm{ha}^{-1}, \mathrm{~T}_{2}$ $=\mathrm{PR}$ at $5 \mathrm{t} \mathrm{ha}^{-1}, \mathrm{~T}_{3}=\mathrm{PR}$ at $6 \mathrm{tha}^{-1}, \mathrm{~T}_{4}=$ Mustard oil cake (MOC) at $300 \mathrm{~kg} \mathrm{ha}^{-1}, \mathrm{~T}_{5}=\mathrm{MOC}$ at $500 \mathrm{~kg} \mathrm{ha}^{-1}$, $\mathrm{T}_{6}=$ Neem oil cake (NOC) at $300 \mathrm{~kg} \mathrm{ha}^{-1}, \mathrm{~T}_{7}=\mathrm{NOC}$ at $500 \mathrm{~kg} \mathrm{ha}^{-1}, \mathrm{~T}_{8}=$ Sawdust burning and $\mathrm{T}_{9}=$ Control. The organic amendments such as poultry refuse (PR), mustard oil cake (MOC) and neem oil cake (NOC) were incorporated and mixed thoroughly into soil before 25 days of seed tuber planting. Burnt sawdust was applied one day before planting of seed tubers. Urea, triple super phosphate (TSP), muriate of potash (MoP), Gypsum, zinc sulphate and boric acid were applied at the rate of $350,175,340,120,14$ and $5 \mathrm{~kg}$ per hectare, respectively. The entire amount of TSP, MoP, gypsum, zinc sulphate, boron and half of urea were applied at the time of final land preparation. The remaining amount of urea was applied at 30 DAP (days after planting). Intercultural operations such as weeding and mulching were done as and when required. Irrigations were given four times during the whole growing season. First time, light irrigation was applied at 7 days after planting (DAP) to ensure proper germination. Second irrigation was given at 30 DAP followed by earthing up and side-dressing (urea fertilizers). Third and fourth irrigations were applied at 48 and 63 DAP, respectively. Dithen M45 $2 \mathrm{~g} \mathrm{~L}-1$ was sprayed at 50 DAP to prevent the late blight disease.

\section{Tuber Transplanting}

The study was conducted in previously Rhizoctonia solani infested soil. Potato seed tubers were planted with a spacing of $60 \times 25 \mathrm{~cm}$ on 30 November of 2008. Potato was harvested on 27 February of 2009.

\section{Data collection}

The germination per cent, number of stems per hill and plant height were recorded at 30,50 and 60 DAP, respectively. The yield data were noted at harvest. The disease incidence $(\%)$ and percent disease index (PDI) were assessed at 70 DAP. To record disease incidence, twenty plants were randomly selected from each unit plot at 70 DAP, uprooted carefully, washed with running tap water and checked for infection. Numbers of infected and healthy plants were counted and percent disease incidence was calculated based on total number of plants checked according to the formulae:

Diseuse irciclence $(\%)=\frac{\text { Number of infected plants }}{\text { Total number of plants checlied }} \times 100$

At 70 DAP, severity of stolon infection was indexed on a 0-6 indexing scale (BAKR, et al. 2010), where $0=$ No symptom on stolon, $1=$ minute brown lesion on stolon or root, $2=$ moderately brown lesion on stolon and curling tendency on central leaf, $3=$ stolon symptom discolored accompanied by brown discoloration on roots, $4=$ brown to black discoloration on underground parts, tissue discoloration and curling of growing leaves, 5 $=$ profuse emerging of auxiliary leaves, leaf size reduced markedly and pale green on leaf margin, and $6=$ production of aerial tuber with green color. Finally, it was converted into per cent disease index (PDI) following the formulae out line by BAKR, et al. (2010).

The analysis of variance (ANOVA) for various crop characters and disease incidence was performed following $\mathrm{F}$ test. When $\mathrm{F}$ was significant at the $p<0.05$ level, treatments means were separated using LSD test. Data were analyzed following standard procedure using SAS software (version 9.3). Computation and preparation of graphs were created using Microsoft Excel 2003 Program. 


\section{RESULTS}

Effect of organic amendment on growth parameters of potato

The germination (\%) and growth parameters of potato were significantly influenced by the stem canker pathogen under different organic amendments. (Table 1). The germination (\%) ranged from 88.7 to 97.3 , having the maximum germination in poultry refuse $6 \mathrm{tha}^{-1}$ and the minimum was in the control.

Table 1. Effect of organic amendment on germination and growth parameters of potato

\begin{tabular}{|c|c|c|c|}
\hline Treatment & Germination (\%) & No. of stem hill ${ }^{-1}$ & Plant height $(\mathrm{cm})$ \\
\hline $\mathrm{T}_{1}=\mathrm{PR}\left(4 \mathrm{tha}^{-1}\right)$ & $\begin{array}{l}91.3 \mathrm{c} \\
(9.47)\end{array}$ & $4.70 \mathrm{~b}$ & $57.3 \mathrm{ab}$ \\
\hline $\mathrm{T}_{2}=\mathrm{PR}\left(5 \mathrm{tha}^{-1}\right)$ & $\begin{array}{c}94.6 \mathrm{ab} \\
(9.73)\end{array}$ & $4.93 \mathrm{~b}$ & $58.9 \mathrm{ab}$ \\
\hline $\mathrm{T}_{3}=\mathrm{PR}\left(6 \mathrm{tha}^{-1}\right)$ & $\begin{array}{l}97.3 \mathrm{a} \\
(9.87)\end{array}$ & $5.30 \mathrm{a}$ & $62.2 \mathrm{a}$ \\
\hline $\mathrm{T}_{4}=\operatorname{MOC}\left(300 \mathrm{~kg} \mathrm{ha}^{-1}\right)$ & $\begin{array}{l}90.4 \mathrm{c} \\
(9.42)\end{array}$ & $4.25 \mathrm{~cd}$ & $56.7 \mathrm{ab}$ \\
\hline $\mathrm{T}_{5}=\operatorname{MOC}\left(500 \mathrm{~kg} \mathrm{ha}^{-1}\right)$ & $\begin{array}{l}92.1 \mathrm{c} \\
(9.52)\end{array}$ & $4.20 \mathrm{~cd}$ & $56.8 \mathrm{ab}$ \\
\hline $\mathrm{T}_{6}=\operatorname{NOC}\left(300 \mathrm{~kg} \mathrm{ha}^{-1}\right)$ & $\begin{array}{l}91.7 \mathrm{c} \\
(9.49)\end{array}$ & $4.05 \mathrm{~d}$ & $57.1 \mathrm{ab}$ \\
\hline $\mathrm{T}_{7}=\mathrm{NOC}\left(500 \mathrm{~kg} \mathrm{ha}^{-1}\right)$ & $\begin{array}{c}92.1 \mathrm{bc} \\
(9.58)\end{array}$ & $4.03 \mathrm{~d}$ & $57.2 \mathrm{ab}$ \\
\hline $\mathrm{T}_{8}=$ Sawdust burning & $\begin{array}{l}90.8 \mathrm{c} \\
(9.44)\end{array}$ & $4.38 \mathrm{c}$ & $56.7 \mathrm{ab}$ \\
\hline $\mathrm{T}_{9}=$ Control & $\begin{array}{l}88.7 \mathrm{c} \\
(9.42)\end{array}$ & $4.00 \mathrm{~d}$ & $53.2 \mathrm{~b}$ \\
\hline $\mathrm{CV}(\%)$ & 1.28 & 11.03 & 7.33 \\
\hline
\end{tabular}

Means followed by the same letter (s) within a column did not differ significantly at $5 \%$ level of LSD. Notes: $\mathrm{T}_{1}=$ Poultry refuse (PR) at $4 \mathrm{t} \mathrm{ha}^{-1}, \mathrm{~T}_{2}=\mathrm{PR}$ at $5 \mathrm{t} \mathrm{ha}^{-1}, \mathrm{~T}_{3}=\mathrm{PR}$ at $6 \mathrm{t} \mathrm{ha}^{-1}, \mathrm{~T}_{4}=$ Mustard oil cake (MOC) at $300 \mathrm{~kg} \mathrm{ha}^{-1}, \mathrm{~T}_{5}=$ MOC at $500 \mathrm{~kg} \mathrm{ha}{ }^{-1}, \mathrm{~T}_{6}=\mathrm{Neem} \mathrm{oil}$ cake (NOC) at $300 \mathrm{~kg} \mathrm{ha}^{-1}, \mathrm{~T}_{7}=\mathrm{NOC}$ at $500 \mathrm{~kg} \mathrm{ha}^{-1}, \mathrm{~T}_{8}=$ Sawdust burining, $\mathrm{T}_{9}=$ Control.

Poultry refuse 5 and $6 \mathrm{t} \mathrm{ha}^{-1}$ showed similar germination (\%). Number of stem hill ${ }^{-1}$ was positively influenced by the different treatments but their effect was not significant. Poultry refuse $6 \mathrm{tha}$ ${ }^{1}$ showed highest number of stem hill $^{-1}$ (5.30). The minimum number of stem hill $^{-1}$ (4.00) was found in the control (Table 1). The plant height varied from 53.2 to $62.2 \mathrm{~cm}$. The highest plant height was found in poultry refuse at $6 \mathrm{t} \mathrm{ha}^{-1}$ and the lowest plant height was in the control (Table 1). Among the poultry refuses, it was observed that germination (\%), number of stem hill $^{-1}$ and plant height were increased with increase in amount of poultry refuse.

\section{Effect of organic amendment on the incidence} $(\%)$ and percent disease index of potato

The incidence and severity of stem canker were significantly influenced by the organic amendments. 
Table 2. Effect of organic amendment on the incidence of stem canker of potato

\begin{tabular}{lcc}
\hline Treatment & Incidence $(\%)$ & PDI \\
\hline $\mathrm{T}_{1}=$ PR $\left(4 \mathrm{t} \mathrm{ha}^{-1}\right)$ & $25.7 \mathrm{~b}$ & $13.1 \mathrm{bc}$ \\
$\mathrm{T}_{2}=\mathrm{PR}\left(5 \mathrm{t} \mathrm{ha}^{-1}\right)$ & $(2.70)$ & $(3.62)$ \\
& $18.3 \mathrm{~cd}$ & $10.2 \mathrm{c}$ \\
$\mathrm{T}_{3}=\mathrm{PR}\left(6 \mathrm{t} \mathrm{ha}^{-1}\right)$ & $(2.39)$ & $(3.17)$ \\
& $17.4 \mathrm{~d}$ & $9.99 \mathrm{c}$ \\
$\mathrm{T}_{4}=$ MOC $\left(300 \mathrm{~kg} \mathrm{ha}^{-1}\right)$ & $(2.36)$ & $(3.14)$ \\
& $24.0 \mathrm{~b}$ & $12.5 \mathrm{bc}$ \\
$\mathrm{T}_{5}=$ MOC $\left(500 \mathrm{~kg} \mathrm{ha}^{-1}\right)$ & $(2.72)$ & $(3.53)$ \\
& $20.0 \mathrm{~cd}$ & $11.1 \mathrm{~b}$ \\
$\mathrm{~T}_{6}=\operatorname{NOC}\left(300 \mathrm{~kg} \mathrm{ha}^{-1}\right)$ & $(2.46)$ & $(3.70)$ \\
& $25.0 \mathrm{~b}$ & $14.8 \mathrm{~b}$ \\
$\mathrm{~T}_{7}=$ NOC $\left(500 \mathrm{~kg} \mathrm{ha}^{-1}\right)$ & $(2.76)$ & $(3.83)$ \\
& $21.7 \mathrm{~cd}$ & $12.2 \mathrm{bc}$ \\
$\mathrm{T}_{8}=$ Sawdust burning & $(2.64)$ & $(3.49)$ \\
& $22.5 \mathrm{bcd}$ & $12.8 \mathrm{bc}$ \\
$\mathrm{T}_{9}=$ Control & $(2.62)$ & $(3.57)$ \\
& $31.3 \mathrm{a}$ & $19.6 \mathrm{a}$ \\
$\mathrm{CV} \%$ & $(3.09)$ & $8.32)$ \\
\hline
\end{tabular}

Means followed by the same letter (s) within a column did not differ significantly at 5\% level of LSD.

The incidence of stem canker ranged from 17.5 to $31.3 \%$. The highest incidence of stem canker $(31.3 \%)$ was found in the control (Figure 1), which was significantly higher than the organic amendments (Table 2). The lowest incidence of stem canker $(17.5 \%)$ was recorded in poultry waste $6 \mathrm{t} \mathrm{ha}^{-1}$ (Figure 1). Among the organic amendments, $\mathrm{T}_{1}, \mathrm{~T}_{4}$ and $\mathrm{T}_{6}$ showed statistically similar and higher incidence $(\%)$ of stem canker, where minimum rate of respective organic manure was applied (Table 2). The percent disease index varied from 9.99 to 19.6. The control showed the maximum PDI (19.6), which was significantly different from the other treatments. The minimum PDI (9.99) was found in poultry waste $6 \mathrm{tha}^{-1}$, which was identical to poultry waste $5 \mathrm{tha}^{-1}(10.2)$. It was found that the incidence of stem canker and per cent disease index were decreased with increase in rate of organic matter. Among the organic matters, poultry refuse showed better performance.

\section{Effect of organic amendment on the number of black scurf infected potato tubers}

The numbers of infected tuber showing different types of symptoms of black scurf of potato are presented in Table 3. The control showed the highest number of russet tubers (16.0), which was significantly higher than the organic amended treatments. The lowest number of russet tubers was found in poultry refuse $6 \mathrm{t} \mathrm{ha}^{-1}$ (Table 3). Poultry waste $5 \mathrm{t} \mathrm{ha}^{-1}$ and sawdust burning showed identical number of russet tubers (8). The number of deformed tubers was significantly variable among the treatments. It ranged from 4.0 to 9.0 plot $^{-1}$. The minimum number of deformed tubers was found in poultry waste $6 \mathrm{t} \mathrm{ha}^{-1}$ (Table 3) which was significantly lower than the other treatments. The maximum number of deformed tubers was in the control (Table 3).

The number of selenotia bearing tuber was significantly influenced by the organic amendments. The control showed the significantly highest sclerotia bearing tubers (57.0) which were followed by neem oil cake $300 \mathrm{~kg} \mathrm{ha}^{-1}(45.0)$ and poultry refuse $4 \mathrm{t} \mathrm{ha}^{-1}$ (42.5). The lowest number of sclerotia bearing tubers (30.3) was found in poultry refuse $6 \mathrm{t}$ $\mathrm{ha}^{-1}$.

\section{Effect of organic amendments on the weight of black scurf infected tubers}

The weight of black scurf infected tubers was significantly influenced by the organic amendments (Table 4).

The significantly lower russet tubers $(500 \mathrm{~g}$ plot $^{-1}$ ) were found in poultry waste $6 \mathrm{tha}^{-1}$ and the highest (1350 $\mathrm{g} \mathrm{plot}^{-1}$ ) was in the control (Table 4). Poultry waste $6 \mathrm{t} \mathrm{ha}^{-1}$ also showed the lowest deformed tubers $\left(300 \mathrm{~g}\right.$ plot $\left.^{-1}\right)$, which was statistically similar with poultry waste 4 and $5 \mathrm{t} \mathrm{ha}^{-1}$. The maximum deformed tubers $\left(600 \mathrm{~g} \mathrm{plot}^{-1}\right)$ were in the control (Table 4). The highest sclerotia infected tubers $\left(400 \mathrm{~g} \mathrm{plot}^{-1}\right)$ were recorded in the control, which was significantly higher than the other treatments. The lowest selerotia infected 
tubers $\left(21080 \mathrm{~g} \mathrm{plot}^{-1}\right)$ were found in poultry waste $6 \mathrm{t} \mathrm{ha}^{-1}$ (Table 4).

Table 3. Effect of organic amendments on the number of black scurf infected tubers

\begin{tabular}{lccc}
\hline Treatment & \multicolumn{3}{c}{ Number of infected tuber plot $^{-1}$} \\
\cline { 2 - 4 } & Russet & Deformed & Sclerotia \\
\hline $\mathrm{T}_{1}=$ PR $\left(4 \mathrm{ha}^{-1}\right)$ & $10.0 \mathrm{~d}$ & $7.00 \mathrm{c}$ & $42.5 \mathrm{bc}$ \\
$\mathrm{T}_{2}=\mathrm{PR}\left(5 \mathrm{ha}^{-1}\right)$ & $8.00 \mathrm{e}$ & $5.25 \mathrm{~d}$ & $33.0 \mathrm{de}$ \\
$\mathrm{T}_{3}=$ PR $\left(6 \mathrm{ha}^{-1}\right)$ & $6.50 \mathrm{f}$ & $4.00 \mathrm{e}$ & $30.3 \mathrm{e}$ \\
$\mathrm{T}_{4}=$ MOC $\left(300 \mathrm{~kg} \mathrm{ha}^{-1}\right)$ & $12.0 \mathrm{~b}$ & $6.50 \mathrm{c}$ & $36.8 \mathrm{de}$ \\
$\mathrm{T}_{5}=$ MOC $\left(500 \mathrm{~kg} \mathrm{ha}^{-1}\right)$ & $10.3 \mathrm{~cd}$ & $5.00 \mathrm{~d}$ & $31.3 \mathrm{e}$ \\
$\mathrm{T}_{6}=$ NOC $\left(300 \mathrm{~kg} \mathrm{ha}^{-1}\right)$ & $11.3 \mathrm{bc}$ & $8.00 \mathrm{~b}$ & $45.0 \mathrm{~b}$ \\
$\mathrm{~T}_{7}=$ NOC $\left(500 \mathrm{~kg} \mathrm{ha}^{-1}\right)$ & $9.25 \mathrm{~d}$ & $6.25 \mathrm{c}$ & $35.3 \mathrm{~d}$ \\
$\mathrm{~T}_{8}=$ Sawdust burning & $8.00 \mathrm{e}$ & $7.00 \mathrm{c}$ & $39.3 \mathrm{c}$ \\
$\mathrm{T}_{9}=$ Control & $16.0 \mathrm{a}$ & $9.00 \mathrm{a}$ & $57.0 \mathrm{a}$ \\
$\mathrm{CV}$ (\%) & 6.04 & 6.88 & 5.12
\end{tabular}

Means followed by the same letter (s) within a column did not differ significantly at 5\% level of LSD.

Table 4. Effect of organic amendment of field soil on the weight of black scurf infected tubers

\begin{tabular}{lccc}
\hline Treatment & \multicolumn{3}{c}{ Weight } \\
\cline { 2 - 4 } & Russet & Deformed & Sclerotia \\
\hline $\mathrm{T}_{1}=$ PR $\left(4 \mathrm{t} \mathrm{ha}^{-1}\right)$ & $900 \mathrm{~d}$ & $530 \mathrm{~b}$ & $3030 \mathrm{~b}$ \\
$\mathrm{~T}_{2}=\mathrm{PR}\left(5 \mathrm{ha}^{-1}\right)$ & $580 \mathrm{f}$ & $350 \mathrm{~cd}$ & $2360 \mathrm{ef}$ \\
$\mathrm{T}_{3}=\mathrm{PR}\left(6 \mathrm{ha}^{-1}\right)$ & $500 \mathrm{~g}$ & $300 \mathrm{e}$ & $2180 \mathrm{f}$ \\
$\mathrm{T}_{4}=$ MOC $\left(300 \mathrm{~kg} \mathrm{ha}^{-1}\right)$ & $1000 \mathrm{~b}$ & $380 \mathrm{c}$ & $2680 \mathrm{~cd}$ \\
$\mathrm{~T}_{5}=$ MOC $\left(500 \mathrm{~kg} \mathrm{ha}^{-1}\right)$ & $950 \mathrm{c}$ & $330 \mathrm{de}$ & $2230 \mathrm{f}$ \\
$\mathrm{T}_{6}=$ NOC $\left(300 \mathrm{~kg} \mathrm{ha}^{-1}\right)$ & $680 \mathrm{e}$ & $580 \mathrm{a}$ & $3150 \mathrm{~b}$ \\
$\mathrm{~T}_{7}=$ NOC $\left(500 \mathrm{~kg} \mathrm{ha}^{-1}\right)$ & $700 \mathrm{e}$ & $500 \mathrm{~b}$ & $2500 \mathrm{de}$ \\
$\mathrm{T}_{8}=$ Sawdust burning & $680 \mathrm{e}$ & $530 \mathrm{~b}$ & $2800 \mathrm{c}$ \\
$\mathrm{T}_{9}=$ Control & $1350 \mathrm{a}$ & $600 \mathrm{a}$ & $4100 \mathrm{a}$ \\
$\mathrm{CV} \%$ & 3.18 & 6.05 & 4.31 \\
\hline
\end{tabular}

Means followed by the same letter (s) within a column did not differ significantly at 5\% level of LSD.

\section{Effect of organic amendments on the healthy and infected tubers}

The numbers of infected and healthy tubers were significantly variable among different organic manures. The highest number of infected tubers (82) was obtained in the control, which was significantly higher than the other treatments (Figure 1). The lowest infected tubers (40.7) were in poultry waste 6 $\mathrm{t} \mathrm{ha}^{-1}$. The number of healthy tubers per plot ranged from 103 to 204 , having the highest in poultry waste $6 \mathrm{t} \mathrm{ha}^{-1}$, which was identical to poultry waste $5 \mathrm{t} \mathrm{ha}^{-}$ 1. The minimum healthy tubers (103 plot $\left.^{-1}\right)$ were noted in the control (Figure 1).
The weight of healthy and infected tubers was also positively influenced by the organic amendments. The highest weight of infected tubers was found in the control and the lowest was in poultry waste $6 \mathrm{t} \mathrm{ha}^{-1}$. The reverse is true in case of healthy tuber weight per plot (Figure2).

\section{Potato tuber yield}

The effects of organic amendments on the tuber yield of potato are presented in Table 5. The tuber yield ranged from 14.7 to $20.5 \mathrm{tha}^{-1}$. The highest potato tuber yield was recorded in poultry refuse $6 \mathrm{t} \mathrm{ha}^{-1}$, which was significantly higher than the other treatments. The lowest potato tuber yield (14.7 tha $^{-1}$ ) was found in the control (Table 5). 


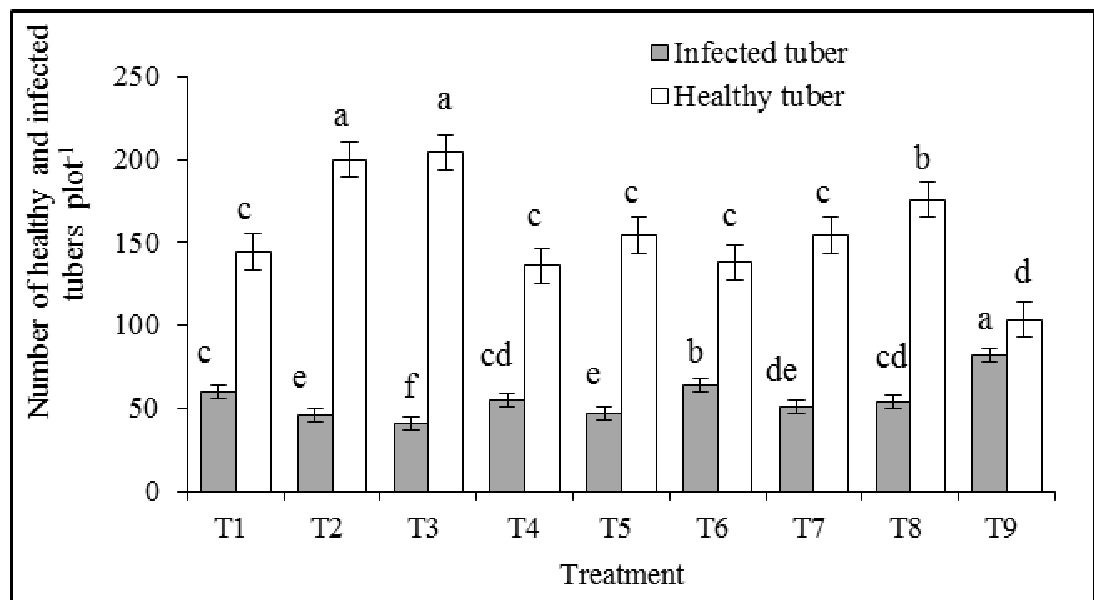

Figure1. The number of healthy and infected tubers of potato per plot as influenced by different organic amendments.

Notes: $\mathrm{T}_{1}=$ Poultry refuse (PR) at $4 \mathrm{tha}{ }^{-1}, \mathrm{~T}_{2}=\mathrm{PR}$ at $5 \mathrm{t} \mathrm{ha}^{-1}, \mathrm{~T}_{3}=\mathrm{PR}$ at $6 \mathrm{t} \mathrm{ha}^{-1}, \mathrm{~T}_{4}=$ Mustard oil cake (MOC) at $300 \mathrm{~kg} \mathrm{ha}^{-1}, \mathrm{~T}_{5}=$ MOC at $500 \mathrm{~kg} \mathrm{ha}^{-1}, \mathrm{~T}_{6}=$ Neem oil cake (NOC) at $300 \mathrm{~kg} \mathrm{ha}^{-1}, \mathrm{~T}_{7}=$ NOC at $500 \mathrm{~kg} \mathrm{ha}^{-1}, \mathrm{~T}_{8}=$ Sawdust burining, $\mathrm{T}_{9}=$ Control.

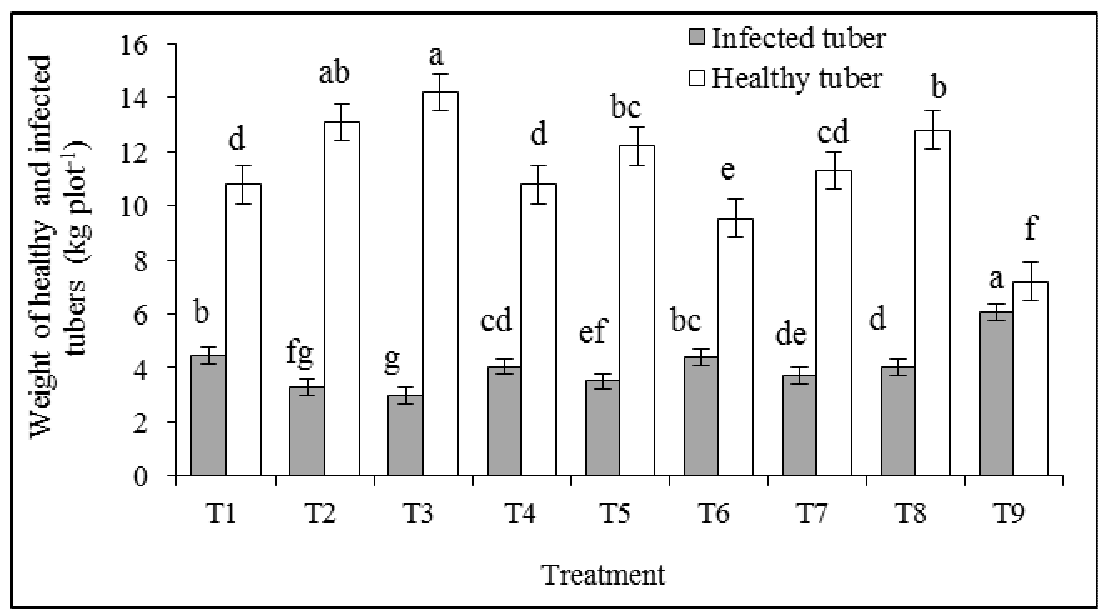

Figure 2. The weight of healthy and infected tubers of potato per plot as influenced by different organic amendments.

Table 5. Effect of organic amendment of field soil on the tuber yield as affected by stem canker and black scurf of potato

\begin{tabular}{lc}
\hline Treatment & Yield $\left(\mathrm{t} \mathrm{ha}^{-1}\right)$ \\
\hline $\mathrm{T}_{1}=$ PR $\left(4 \mathrm{t} \mathrm{ha}^{-1}\right)$ & $16.7 \mathrm{~cd}$ \\
$\mathrm{~T}_{2}=\mathrm{PR}\left(5 \mathrm{t} \mathrm{ha}^{-1}\right)$ & $18.2 \mathrm{bc}$ \\
$\mathrm{T}_{3}=\operatorname{PR}\left(6 \mathrm{t} \mathrm{ha}^{-1}\right)$ & $20.5 \mathrm{a}$ \\
$\mathrm{T}_{4}=\operatorname{MOC}\left(300 \mathrm{~kg} \mathrm{ha}^{-1}\right)$ & $16.5 \mathrm{~cd}$ \\
$\mathrm{~T}_{5}=\operatorname{MOC}\left(500 \mathrm{~kg} \mathrm{ha}^{-1}\right)$ & $17.2 \mathrm{~b}-\mathrm{d}$ \\
$\mathrm{T}_{6}=\operatorname{NOC}\left(300 \mathrm{~kg} \mathrm{ha}^{-1}\right)$ & $15.5 \mathrm{de}$ \\
$\mathrm{T}_{7}=\operatorname{NOC}\left(500 \mathrm{~kg} \mathrm{ha}^{-1}\right)$ & $16.7 \mathrm{~cd}$ \\
$\mathrm{~T}_{8}=$ Sawdust burning & $18.5 \mathrm{~b}$ \\
$\mathrm{~T}_{9}=$ Control & $14.7 \mathrm{e}$ \\
$\mathrm{CV}(\%)$ & 6.05
\end{tabular}

Means followed by the same letter (s) within a column did not differ significantly at 5\% level of LSD. 


\section{DISCUSSION}

Organic manure amendments such as poultry waste mustard oil cake and sawdust were tested in controlling stem canker and black scurf disease. Results from the study revealed that the organic amendments significantly reduced the infection of the disease. Among the organic manures, poultry manure showed the better performance in relation to disease reduction and yield increment. The lowest incidence (\%) and per cent disease index were found in $\mathrm{T}_{3}$ where $6 \mathrm{t} \mathrm{ha}^{-1}$ poultry waste was incorporated. The number of russet, deformed and sclerotia bearing tubers were lowest in the maximum organic amended plots. It was also observed that disease incidence and (\%) per cent disease index were decreased with increase in amount of poultry refuse. But reverse is true in case of yield attributes and yield of tuber while yield attributes and yield were increased with increase in quantity of poultry refuse and this might be due to (i) add nutrient to the soil thereby increasing the soil fertility which improves plant growth and makes the plant less prone to infection by pathogens (MUHAMMAD et al., 2001) (ii) organic manure may release some hormones or organic compound which suppressed stem canker disease. Organic amendments may exert stimulatory or inhibitory effects on the microbial plant pathogen populations and disease development. They may either prevent infection by activating the soil microflora potentially competitive with or antagonistic to plant pathogens present in the soil or control plant pathogens by producing toxic compounds in the soil, when they decompose in the soil (NARAYANASAMY, 2013; SWAIN et al., 2006).

The common scab of potato (Streptomyces scabies) was effectively managed by an organic amendment (poultry manure at $2 \mathrm{MT} \mathrm{ha}^{-1}$ ) with bioagent Pseudomonas fluorescens (CHAUDHARI et al., 2003). Shaikh and Ghaffar (2004) reported that the sclerotial population of Macrophomina phaseolina was declined after 15 days of application of poultry manure. The weight of black scurf tubers was minimum when the integrated approach of PR + seed Bavistin $(0.1 \%)$ and drenching was applied. Integration of PR + Vitavax $(0.2 \%)$ soil drenching was effective (HOSSAIN et al., 2009). Use of poultry manures and seed treatment with Vitavax200 and poultry manures and soil drenching with Bavistin showed better performance in reducing stem canker and black scurf disease of potato (HOSSAIN et al., 2008). Sawdust, mustard oil cake and some fungicides were tested against stem canker and black scurf of potato. The growth of $R$. solani was completely inhibited when the sawdust amendments at the concentration of $16000 \mathrm{ppm}$ and onward (EMRAM et al., 2012).

Effectiveness of organic amendments against Rhizoctonia solani was also reported by several workers (SINGH et al., 1972; FAQIR et al., 1995; SCHOLTE; LOOTSMA, 1998; TSROR et al., 2001; CHOUDHORI et al., 2003; SHAIKH; GHAFFAR, 2004; DEY et al., 2005). DEY et al. (2005) reported that poultry waste $3 \mathrm{t} \mathrm{ha}^{-1}$ performed well in reducing stem canker and black scurf disease and increased yield of potato. TSROR et al. (2001) reported that cattle manure compost in furrow markedly reduced black scurf incidence. Scholte and Lootsma (1998) narrated that organic amendments reduced disease severity and increased populations of mycophagous soil organisms. Positive response of mustard oil cake against $R$. solani has been demonstrated by Singh et al. (1972); Scholte and Lootsma (1998); Shaikha and Ghaffar (2004) and Dey et al. (2005). The sawdust was found comparatively less effective than the poultry waste. Shikha and Ghaffar (2004) also reported similar results. In contrast Dey et al. (2004) and Singh et al. (1972) claimed that sawdust amendment significantly reduced the stem canker and black scurf infection and reduced sclerotial population in soil, which vary with our findings.

\section{CONCLUSIONS}

The organic manure significantly influenced the disease incidence, yield attributes and yield of potato.

The lowest disease incidence $(17.5 \%)$ and per cent disease index (9.99) were found in $T_{3}$ (poultry waste at $6 \mathrm{tha}^{-1}$ ).

The minimum russet, deformed and Sclerotia infected tubers were also recorded in $\mathrm{T}_{3}$.

The highest healthy tubers and tuber yield were found in the same treatment. Therefore, poultry manure $6 \mathrm{t} \mathrm{ha}^{-1}$ along with recommended dose of chemical fertilizer can be recommended to produce healthy tubers and maximum tuber yield of potato.

\section{ACKNOWLEDGEMENTS}

We are thankful to the Bangladesh Agricultural Research Institute for financial support during the study period. 
RESUMO: O experimento foi conduzido no (Centro de Pesquisa em Tubérculos ) Tuber Crops Research Centre, Bari, Bogra durante 2008-2009 para avaliar a alteração orgânica e controlar o cancro da haste e Black Scurf da batata. Os diferentes tipos de alterações orgânicas foram: T1 = Poultry recusar (PR) a 4 t ha-1, T2 = PR a 5 t ha-1, T3 = PR em 6 t ha-1, T4 = bolo de óleo de mostarda (MOC) em $300 \mathrm{~kg}$ ha-1, T5 = MOC em $500 \mathrm{~kg}$ ha-1, T6 = bolo de óleo de Neem (NOC) em $300 \mathrm{~kg}$ ha-1, T7 = NOC em $500 \mathrm{~kg}$ ha-1, T8 = queima de serragem e T9 = Controle. O delineamento experimental foi em blocos casualizados (RCBD) com quatro repetições. A alteração orgânica influenciou significativamente a incidência da doença, os atributos de rendimento e produtividade da batata. A menor incidência da doença $(17,5 \%)$ por cento do índice de doença $(9,99)$ foram encontrados em T3 (resíduos de aves a 6 t ha-1). O russet mínimo, deformado e Sclerotia tubérculos infectados também foram registrados em resíduos de aves a $6 \mathrm{t}$ ha-1. O rendimento mais elevado tubérculos saudáveis e tubérculos foram encontrados no mesmo tratamento. Portanto, aviário $6 \mathrm{t}$ ha-1, juntamente com a dose recomendada de fertilizante químico pode ser recomendado para a produção de tubérculos saudáveis e rendimento máximo dos tubérculos de batata.

KEYWORDS: Alteração orgânica do solo. Cancro da haste. Black scurf. Solanum teberosum.

\section{REFERENCES}

AGRIOS, G. N. Plant Pathology. $4^{\text {th }}$ ed. New York: Academic press, 2005, 214 p.

ALI, M. S.; KHAN, A. L. Pathological constraints of seed potato production in Bangladesh. In: RASHID, M. M.; SIDDIQUE, M. A.; M. M., HUSSAIN (Eds.) Proceedings of the international seminar of Seed production in Bangladesh. Dhaka: BADC, 1990. p. 187-199.

ALI, M. S.; DEY, T. K. (1994) Pathological research on tuber crops in Bangladesh. In: Ahmed, H. U., Alam, M. S., Hasan, D. R., \& Islam, A. (Eds.) Proceedings of Workshop Transfer of Technology of CDP Crops under Research - Extension. Gazipur, Bangladesh: BARI, 1994. p. 149-165.

BAKR, M. A.; HOSSAIN, S.; AHMED, H. U. A guide to disease Identification, Data Recording, Scale and Grading System of Major Diseases of Important Crops. Oilseed Research Center. Bangladesh Agricultural Research Institute, Gazipur, Bangladesh: Training and Communication, 2010. p. 28-31.

CHAUDHARI, S. M.: PATEL, R. N.; KHURANA, S. M. P.; PATEL, K. R. ; RATEL, N. H. Management of common scab of potato. Journal of Indian potato Association, India, v. 30, p. 135-136,2003.

DEY, T. K. ; ASMM, A. L. A. M. ; PRODHAN, M. Z. H. Integrated management of stem canker/ black scurf disease of potato. In : Rashid M. H. (Ed.) Annaual Research Report 2004-05. Tuber Crops Res. Centre (TCRC), Bangladesh Agril. Res. Inst., Gazipur, Bangladesh: TCRC, 2005. p. 69-70.

DEY, T. K.; BARI, M. A.; SAHA, M. K.; RAHMAN, M.; AYUB, A. Effectiveness of organic amendments and chemicals in controlling black scurf disease of potato. Bangladesh Journal of Plant Pathology, Bangladesh, v. 20, p. 17-20, 2004.

EMRAN, H.; AKHTER, M. S. Determination of sawdust concentration for inhibitory effect against Rhizoctonia solani, a causal agent of damping off of cotton fibre. International Research Journal of Applied Life Sciences, Pennsylvania, v. 1, p. 27-34, 2012.

FAQIR, M.; BAJWA, M. N.; NASIR, M. A.; MUHAMMAD, F. Effect of different soil amendments on the incidence of common scab of potato. Pakistan Journal of Phytopathology, Pakistan, v. 7, p. 202-203, 1995.

HASHEM, A. An introduction to the potato seed industary of Bangladesh. In: RASHID, M. M.; SIDDIQUE, M. A.; M. M. HUSSAIN, M. M. (Eds.) International seminar on Seed potato in Bangladesh, Dhaka: BADC, 1990. p. 1-15. 
HOSSAIN, M. I. ; HOSSAIN, M. ; DEY, T. K. Integrated management of stem canker/ black scurf disease of potato. . In : HOSSAIN, M.M., BHUIYAN, M. K. R., HOSSAIN, M. ; B. C. KUNDU (Eds.) Annaual Research Report 2007-08. Tuber Crops Res. Centre (TCRC), Bangladesh Agril. Res. Inst., Gazipur, Bangladesh: TCRC, 2008. p. 96-97.

HOSSAIN, M. I.; HOSSAIN, M.; DEY, T. K. Integrated management of stem canker/ black scurf disease of potato. In : KUNDU, B. C.; DEY, T. K.; HOSSAIN, M.; H. C. MOHOANTA (Eds.) Annaual Research Report 2008-09. Tuber Crops Res. Centre (TCRC), Bangladesh Agril. Res. Inst., Gazipur, Bangladesh: TCRC, 2009. p. 138-139.

ISLAM, M. Z.; ZAMAM, M. M.; HOSSAIN, M. M.; HOSSAIN, A. Integrated nutrient management with liming for potato production in North-West region of Bangladesh. In: KUNDU, B. C.; DEY, T. K.; HOSSAIN, M.; H. C. MOHANTA (Eds.) Annual Research Report 2008-2009. Tuber Crops Research Centre (TCRC), Bangladesh Agril. Res. Inst, Gazipur, Bangladesh: TCRC, 2009. p. 132-134.

KOTCON, J. B.; ROUSE, O. I.; MITCHELL, J. E. Interactions of Verticillium dahliae, Colletotrichum coccodes, Rhizoctonia solani and Pratylenchus penetrans in the early dying syndrome of Russet Burbank potatoes. Phytopathology, USA, v. 75, p. 68-74, 1985.

MUHAMMAD, S.; SUBERU, H. A.; AMUSA, N. A.; AGAJI, M. D. The effect of soil amendment with sawdust and rice husks on the growth and incidence of seedling blight of Tamarindus indica L., caused by Macrophomina phaseolina and Rhizoctonia solani. Moor Journal of Agricultural Research, South Africa, v. 2, p. 40-46, 2001.

NARAYANASAMY, P. Cultural Practices Influencing Biological Management of Crop Diseases. In: Biological Management of Diseases of Crops: Volume 2: Integration of Biological Control Strategies with Crop Disease Management Systems. New York: Springer publishing, v. 2, p. 9-56, 2013.

RHAMAN M, M. M.; ALI, A.; AHMED, M. U.; DEY, T. K. Evaluation of fungicide for seed treatment to control stem canker and black scurf disease (Rhizoctonia solani) of potato. Bangladesh Journal of Plant Pathology, Bangladesh, v. 30, p. 23-27, 2014.

RAHMAN, M. L.; HOSSAIN, M. M.; ASHRAFUZZAMAN, M.; ISLAM, T. Effect of inioculum levels of (Rhizoctonai solani) on the incidence of black scurf disease of potato. Bangladesh Journal of Plant Pathology, Bangladesh, v. 12, p. 21-22, 1996.

RAHMAN, M. M. Integrated managent of stem canker and black scurf of potato. $\mathrm{Ph}$.D. dissertation, Plant Pathology Department. Bangladesh Agril. Uni., Mymensingh: BAU, 2011.

SCHOLTE, K. ; LOOTSMA, M. Effect of farmyard manure and green manure crops on populations of mycophagous soil fauna and Rhizoctonia stem canker of potato. Pedobiologia, Netherlands, v. 42, p. 223-231, 1998.

SHAIKH, A. H.; GHAFFAR, A. Effect of poultry manure and sawdust on survival of sclerotia of Macrophomina phaseolina in soil. Pakistan Journal of Bototany, Pakistan, v. 36, p. 425-428, 2004.

SINGH, R. S.; CHAUBE, H. S.; SING. Studies on the control of black scurf disease of potato. Indian Phytopathology, India, v. 25, p. 343-349, 1972.

SWAIN, S.; HARNIK, T.; MEJIA-CHANG, M.; HAYDEN, K.; BAKX, W.; CREQUE, J.; GARBELOTTO, M. Composting is an effective treatment option for sanitization of Phytophthora ramorum -infected plant material. Journal of Applied Microbiology, UK, v.101,p. 815-827, 2006. 
SWAMINATHAN, M. S. Potato for global security. In: KHURANA, S. M. P.; SHEKHAWAT, G. S.; S. K. PANDEY (Eds.) Potato Global Research and Development. Shimla, India: Indian Potato Association, 2000. $302 \mathrm{p}$.

TSROR, I.; BARAK, R.; B. SNEH. Biological control of black scurf of potato under organic management. Crop Protection, England, v. 20, p. 145-150, 2001. 